\title{
TKO USMJERAVA SVJETSKE TURISTIČKE TOKOVE
}

\begin{abstract}
Dinamika rasta međunarodnog turističkog prometa u ovom se radu analizira s aspekta organiziranih putovanja na europskom turističkom tržištu. Komparativna analiza razvoja organiziranih putovanja na vodećim turistički receptivnim tržištima Europe podupire tezu o visokoj korelaciji između turoperatora, čarterskog zrakoplovnog prijevoza i razvoja međunarodnog turizma te geografske distribucije međunarodnog turističkog prometa. Konsolidacijski i integracijski procesi na europskom turističkom tržištu rezultirali su promjenom strukture europskog turističkog tržišta kao i promjenom strukture lanca vrijednosti u turizmu. Ulaganjem kineskog kapitala u područje turizma unose se daljnje promjene u strukturu turističkog tržišta. Realokacijom kapitala i širenjem interesa multinacionalnih korporacija (MNC) u područje turizma uspostavljena je kontrola $u$ domeni organiziranih putovanja nad tokovima međunarodne turističke potražnje i razvoja međunarodnog turizma.
\end{abstract}

Ključne riječi: međunarodni turizam; organizirana putovanja; turoperatori; konsolidacijski procesi; MNC u turizmu.

\section{UVOD}

$\mathrm{U}$ analizama međunarodnog turističkog prometa u svijetu obično se naglašava stalan rast broja turističkih dolazaka, ostvarenih noćenja te realiziranih prihoda od inozemne potrošnje. Ti podaci ukazuju na vrlo izraženu dinamiku rasta turističke aktivnosti u svijetu. Kretanja međunarodnog turističkog prometa od 1950. godine, kada je ostvareno 25 milijuna inozemnih turističkih dolazaka i 2,1 milijarda dolara prihoda, do 2017. godine, s realiziranih 1,326 milijardi inozemnih turističkih dolazaka i 1,340 bilijardi dolara prihoda (UNWTO 2018), upućuju na zaključak da „putovanja i turizam predstavljaju važnu ekonomsku aktivnost u većini zemalja u svijetu“ (WTTC 2018). Pridodaju li se tome i procjene Svjetskog turističkog vijeća (WTTC 2018) da putovanja i turizam izravno ostvaruju 3,2\% udjela u svjetskom bruto društvenom proizvodu, odnosno $10,4 \%$ u ukupnom iznosu, da imaju izravan udio u ukupnoj zaposlenosti od oko $10 \%$ te da na tu aktivnost otpada 4,5\%ukupnih investicija u svijetu u 2017. godini, ne treba čuditi činjenica da se turizmu pridodaju epiteti poput najveće 
svjetske industrije, vodećeg gospodarskog sektora u međunarodnoj razmjeni te globalne svjetske aktivnosti. I sve dugoročne prognoze razvoja međunarodne turističke potražnje, uz pretpostavku da će relevantne varijable koje utječu na taj rast odražavati slične tendencije iz prijašnjih razdoblja, predviđaju da će ta potražnja nastaviti rasti po prosječnoj godišnjoj stopi od 3,3\%, što bi trebalo rezultirati s 1,8 milijardi inozemnih turističkih dolazaka do 2030. godine (UNWTO 2017).

Kako često nekritički preuzimamo iznesene podatke, prije iznošenja bilo čijih statistika valja upozoriti na sljedeće: turizam nije industrija, ne može se o njemu raspravljati ni kao o gospodarskom sektoru jer to nije, a davanjem turizmu uloge prioritetnog pravca razvoja i velike ovisnosti gospodarstva o turizmu može se ugroziti i opstojnost održivog razvoja gospodarstva neke zemlje.

Činjenica je da je razvoj turizma odavno postao masovna društvenoekonomska pojava i da je istovremeno prerastao u velik posao. S pravom se stoga mogu postaviti pitanja koji su to poslovni subjekti od 1950. godine naovamo najviše utjecali na omasovljenje turističkih putovanja, na koji su način utjecali na geografsku distribuciju međunarodnog turističkog prometa te tko danas i na koji način usmjerava tokove međunarodne turističke potražnje.

\section{Geografska distribucija međunarodnog turističkog prometa}

Neosporno je da međunarodni turistički promet još od 1950. godine bilježi stalan rast, a da su negativne stope rasta do danas zabilježene samo tri puta, i to između 1973. i 1974. godine zbog naftne krize, 2003. godine zbog rata u Zaljevu te 2009. godine zbog financijske krize i recesije (UNWTO 2017). U razdoblju 1950. - 2012. prosječna stopa rasta iznosila je 6,17\%, ali je od 2008. godine globalna godišnja stopa rasta usporena na 3,07\% (www.stats.areppim.com/stats/ stats_ita.htm).

Iz navedenih podataka lako bi se moglo zaključiti da je turizam prerastao $\mathrm{u}$ globalnu aktivnost $\mathrm{u}$ kojoj ravnomjerno sudjeluje većina zemalja u svijetu. Međutim, iako ne postoje precizni podaci o stvarnom broju svjetske populacije koja je uključena u međunarodna turistička kretanja, Svjetska turistička organizacija procijenila je da se radi o udjelu koji je manji od 10\% (UNWTO 2017). S druge strane, analiza prostorne distribucije međunarodnog turističkog prometa ukazuje na jaku regionalnu koncentraciju kako međunarodnih turističkih dolazaka, tako i ostvarenih prihoda po toj osnovi (tablica 1). 
Tablica 1. Udio turističkih regija svijeta u ukupnom broju međunarodnih turističkih dolazaka

\begin{tabular}{|l|c|c|c|c|c|}
\hline \multirow{2}{*}{ Regija } & \multicolumn{5}{|c|}{ Tržišni udio u ostvarenim međunarodnim turističkim dolascima (u \%) } \\
\cline { 2 - 6 } & $\mathbf{1 9 5 0 .}$ & $\mathbf{1 9 7 0 .}$ & $\mathbf{1 9 9 0 .}$ & $\mathbf{2 0 1 0 .}$ & $\mathbf{2 0 1 6 .}$ \\
\hline Europa & 66,4 & 68,2 & 61,5 & 50,6 & 50,0 \\
\hline Amerika & 29,6 & 25,6 & 20,4 & 16,0 & 16,2 \\
\hline Azija i Pacifik & 0,8 & 3,7 & 12,7 & 21,7 & 24,7 \\
\hline Bliski istok & 1,2 & 1,1 & 2,1 & 6,4 & 4,6 \\
\hline Afrika & 2,0 & 1,4 & 3,3 & 5,3 & 4,7 \\
\hline \multicolumn{1}{|c|}{ SVIJET } & 100,0 & 100,0 & 100,0 & 100,0 & 100,0 \\
\hline
\end{tabular}

Izvor: UNWTO (2017.) Tourism Highlights, za ranije godine: UNWTO (2008.)

Tourism market trends, 2007. Edition - World Overview.

Do 1990-ih godina međunarodni turistički promet bio je koncentriran na samo dvije turističke regije u svijetu: Europu i Ameriku, koje su apsorbirale preko 90\% međunarodnih turističkih dolazaka. Početkom 1990-ih godišnje stope rasta turističkog prometa u tim dvjema regijama postaju niže od svjetskog prosjeka te se njihov udio u relativnom smislu počinje smanjivati, osobito u korist azijsko-pacifičke regije, koja 2004. godine preuzima drugo mjesto na svjetskoj rang-ljestvici regija po ostvarenom fizičkom obujmu međunarodnog turističkog prometa. Razloge takvom razvoju događaja na svjetskom turističkom tržištu treba prije svega tražiti u razvoju općih gospodarskih prilika u svijetu te usmjeravanju investicijskog kapitala na tržišta rastućih ekonomija, posebno u područje istočne Azije.

Aramberri (2009.) s pravom naglašava da se razvoj turizma u svijetu odvija u klasterima i da još uvijek nije dosegnuo visoku razinu globalizacije. Najveće koristi od razvoja međunarodnog turizma imaju razvijene zemlje, što potvrđuju i agregirani podaci koje vodi Svjetska turistička organizacija, prema kojima su razvijene zemlje u 2016. godini apsorbirale $65 \%$ prihoda od međunarodnog turizma, dok na zemlje u razvoju otpada 35\% (UNWTO 2017). Međutim, navedeni podaci ipak prikrivaju širi kontekst neravnomjernog razvoja međunarodnog turizma $u$ svijetu. Naime, analiziraju li se podaci o pojedinačnim udjelima zemalja navedenih regija u ukupno ostvarenim međunarodnim dolascima (tablica 2), a posebno u ostvarenim prihodima po osnovi međunarodne turističke potrošnje (tablica 3), tada koncentracija svjetskog turističkog prometa dolazi osobito do izražaja. 
Tablica 2. Vodeće turistički receptivne zemlje svijeta 1950. - 2016. (prema udjelima u ostvarenim međunarodnim turističkim dolascima)

\begin{tabular}{|c|c|c|c|c|c|}
\hline Rang & $\begin{array}{c}\text { Udio u svijetu } \\
1950 .\end{array}$ & $\begin{array}{c}\text { Udio u svijetu } \\
1970 .\end{array}$ & $\begin{array}{c}\text { Udio u svijetu } \\
1990 .\end{array}$ & $\begin{array}{c}\text { Udio u svijetu } \\
2000 .\end{array}$ & $\begin{array}{c}\text { Udio u svijetu } \\
2016 .\end{array}$ \\
\hline 1 & SAD & Italija & Francuska & Francuska & Francuska \\
\hline 2 & Kanada & Kanada & SAD & SAD & SAD \\
\hline 3 & Italija $71 \%$ & Francuska 43\% & Španjolska 39\% & Španjolska 36\% & Španjolska 29\% \\
\hline 4 & Francuska & Španjolska & Italija & Italija & Kina \\
\hline 5 & Švicarska & SAD & Austrija & Kina & Italija \\
\hline 6 & Irska & Austrija & Meksiko & Vel. Britanija & Vel. Britanija \\
\hline 7 & Austrija & Njemačka & Njemačka & Meksiko & Njemačka \\
\hline 8 & Španjolska 17\% & Švicarska 22\% & Vel. Britanija 18\% & Kanada $15 \%$ & Mexico $14 \%$ \\
\hline 9 & Njemačka & Jugoslavija & Kanada & Njemačka & Tajland \\
\hline 10 & Vel. Britanija & Vel. Britanija & Kina & Austrija & Turska \\
\hline 11 & Norveška & Mađarska & Grčka & Poljska & Austrija \\
\hline 12 & Argentina & Čehoslovačka & Portugal & Grčka & Malezija \\
\hline 13 & Meksiko 9\% & Belgija 10\% & Švicarska 9\% & Portugal 9\% & Hong Kong $11 \%$ \\
\hline 14 & Nizozemska & Bugarska & Jugoslavija & Malezija & Grčka \\
\hline \multirow[t]{2}{*}{15} & Danska & Rumunjska & Malezija & Nizozemska & Ruska Fed. \\
\hline & $\begin{array}{c}\text { Ostale zemlje } \\
\mathbf{3} \%\end{array}$ & $\begin{array}{c}\text { Ostale zemlje } \\
25 \%\end{array}$ & $\begin{array}{c}\text { Ostale zemlje } \\
\mathbf{3 4} \%\end{array}$ & $\begin{array}{c}\text { Ostale zemlje } \\
40 \%\end{array}$ & $\begin{array}{c}\text { Ostale zemlje } \\
47 \%\end{array}$ \\
\hline Ukupno & 25 milijuna & 166 milijuna & 456 milijuna & 683 milijuna & 1235 milijuna \\
\hline
\end{tabular}

Izvor: UNWTO (2017.) Tourism Highlights, za ranije godine: UNWTO (2008.)

Tourism market trends, 2007. Edition - World Overview.

Trend smanjenja tržišnog udjela vodećih 15 turistički receptivnih zemalja dalje se nastavlja, pa su te zemlje u 2016. godini apsorbirale 53\% međunarodnih turističkih dolazaka i 58\% inozemne turističke potrošnje (tablice 2 i 3 ).

Iako većina teoretičara turizma $\mathrm{u}$ svojim analizama vezanim uz razvoj međunarodnih turističkih putovanja od 1950. godine ističe masovnost kao glavnu karakteristiku tih kretanja te posebno naglašava neraskidivu vezu 
Tablica 3. Vodeće turistički receptivne zemlje svijeta 1950. - 2016. (prema udjelima u ostvarenom deviznom priljevu)

\begin{tabular}{|c|c|c|c|c|c|}
\hline Rang & $\begin{array}{c}\text { Udio u svijetu } \\
1950 .\end{array}$ & $\begin{array}{c}\text { Udio u svijetu } \\
1970 .\end{array}$ & $\begin{array}{c}\text { Udio u svijetu } \\
1990 .\end{array}$ & $\begin{array}{c}\text { Udio u svijetu } \\
2000 .\end{array}$ & $\begin{array}{c}\text { Udio u svijetu } \\
2016 .\end{array}$ \\
\hline 1 & SAD & SAD & SAD & SAD & SAD \\
\hline 2 & Kanada & Španjolska & Francuska & Španjolska & Španjolska \\
\hline 3 & Italija $60 \%$ & Italija $45 \%$ & Italija $44 \%$ & Francuska 41\% & Tajland 33\% \\
\hline 4 & Francuska & Njemačka & Španjolska & Italija & Kina \\
\hline 5 & Vel. Britanija & Francuska & Vel. Britanija & Vel. Britanija & Francuska \\
\hline 6 & Švicarska & Kanada & Austrija & Njemačka & Italija \\
\hline 7 & Irska & Vel. Britanija & Njemačka & Kina & Vel. Britanija \\
\hline 8 & Njemačka 15\% & Austrija 22\% & Švicarska 18\% & Austrija 14\% & Njemačka 15\% \\
\hline 9 & Belgija & Švicarska & Kanada & Kanada & Hong Kong \\
\hline 10 & Kuba & Meksiko & Meksiko & Grčka & Australija \\
\hline 11 & Južna Afrika & Nizozemska & Hong Kong & Australija & Japan \\
\hline 12 & Švedska & Belgija & Singapur & Meksiko & Makao \\
\hline 13 & Španjolska 9\% & Danska $10 \%$ & Tajland 8\% & Hong Kong 7\% & Indija $10 \%$ \\
\hline 14 & Norveška & Hong Kong & Australija & Turska & Turska \\
\hline \multirow[t]{2}{*}{15} & Danska & Bivša Jugosl. & Nizozemska & Ruska Fed. & Rep. Koreja \\
\hline & $\begin{array}{c}\text { Ostale zemlje } \\
\mathbf{3} \%\end{array}$ & $\begin{array}{c}\text { Ostale zemlje } \\
21 \%\end{array}$ & $\begin{array}{c}\text { Ostale zemlje } \\
\mathbf{3 0} \%\end{array}$ & $\begin{array}{c}\text { Ostale zemlje } \\
\mathbf{3 8} \%\end{array}$ & $\begin{array}{c}\text { Ostale zemlje } \\
42 \%\end{array}$ \\
\hline Ukupno & 2,1 milijarda & 17 milijardi & 261 milijarda \$ & 476 milijardi \$ & 1220 milijardi \$ \\
\hline
\end{tabular}

Izvor: UNWTO (2017.) Tourism Highlights, za ranije godine: UNWTO (2008.)

Tourism market trends, 2007. Edition - World Overview.

između cijenom vrlo pristupačnih organiziranih (paušalnih) putovanja $u$ inozemne destinacije baziranih na avioprijevozu (posebno čarterskom avioprijevozu) u kombinaciji s uslugama smještaja i prehrane (Burkart and Medlik 1974; Cooper et al. 2008; Goeldner \& Ritchie, 2009; Holloway 1998; Mill and Morrison 1985; Mundt 2011; Youell 1994), nijedan od autora sustavno ne analizira doprinos organizatora putovanja razvoju međunarodnog turizma. Zaobilaženjem 
razmatranja uloge i značenja turoperatora i čarterskih zrakoplovnih kompanija u ukupnom turističkom sustavu, zapostavljaju se i istraživanja kako pozitivnih, tako i negativnih posljedica tih gospodarskih subjekata na razvoj turizma u svijetu. Za mnoge je to samo trgovanje uslugama, čista struka i stoga nedovoljno vrijedno znanstvenog propitivanja. Razloge takvom, pomalo omalovažavajućem, odnosu teorije $\mathrm{u}$ turizmu te zapostavljanju istraživanja $\mathrm{u}$ domeni organiziranih turističkih putovanja i specifičnih temelja ekonomije razmjera upravo u tom segmentu poslovanja u turizmu treba prije svega tražiti u poteškoćama s kojima se znanstvenici susreću kada pokušavaju utvrditi teorijsku bazu na kojoj se temelje svjetski turistički tokovi. S druge strane, već sredinom 1970-ih godina pojavila su se mišljenja da će turoperatori zajedno sa svojim jeftinim proizvodima nestati s tržišta, a pojava interneta te nagli prodor informacijsko-komunikacijske tehnologije i niskotarifnih prijevoznika samo su dodatno učvrstili takve pesimistične stavove (Čavlek 2013). No, kao što će analiza razvoja gospodarskih subjekata $u$ domeni organizacije putovanja u nastavku pokazati, njihovo poslovanje doživljava renesansu i, zahvaljujući relativno brzoj prilagodbi novonastalim okolnostima na tržištu, oni su i dalje vrlo važna karika u sustavu lanca vrijednosti u turizmu.

Nažalost, sustavno praćenje veličine tržišta organiziranih putovanja u svijetu ne postoji. Ono što postoji jesu podaci koji se prate na pojedinim emitivnim ili receptivnim tržištima, ali njihov je nedostatak u tome što su ti podaci često međusobno teško usporedivi jer se u njihovu prikupljanju koriste različite metode koje najčešće nisu ni standardizirane. Stoga je donekle i razumljivo zbog čega se $\mathrm{u}$ teoriji turizma sustavno zaobilaze istraživanja o utjecaju organizatora putovanja na svjetska turistička kretanja. Međutim, postoje drugi načini kojima se može ukazati na njihovu nezaobilaznu ulogu te na nužnost testiranja hipoteze o njihovu velikom utjecaju na razvoj međunarodnog turizma.

\section{Ekonomija razmjera na primjeru turizma}

Kako bismo testirali uzročno-posljedičnu vezu između razvoja poduzetničke aktivnosti u sferi organizacije turističkih paušalnih putovanja, s jedne strane, te razvoja međunarodnog turizma, s druge, morat ćemo se koristiti post hoc procjenom utjecaja organizatora putovanja (turoperatora) i čarterskih zrakoplovnih kompanija na ta kretanja i induktivnom generalizacijom stavova temeljenih na postojećim izvorima te primijeniti deduktivnu metodu u analizi slučajeva s dva vodeća europska tržišta organiziranih putovanja.

Kako je poduzetništvo u domeni organiziranih putovanja pokrenuto u Europi 1950- ih godina i kako su se upravo na dvama najjačim europskim turistič- 
ki emitivnim tržištima razvili i dan-danas najpoznatiji organizatori putovanja u svijetu, a s njima i njihove čarterske zrakoplovne kompanije, opravdanim se čini tu vezu pokušati dokazati na primjeru turoperatora na njemačkom i britanskom tržištu. Naime, ta su dva tržišta do 2000. godine predstavljala čak $20 \%$ svjetskog emitivnog potencijala, a istovremeno $27 \%$ svih poduzetih putovanja $u$ inozemstvo u Europi ostvarivali su turisti iz Njemačke (Poon 2000: 20), od kojih je čak njih $52 \%$ putovalo organizirano u paket-aranžmanima turoperatora (DRV 2000). Istovremeno, prema podacima European Travel Monitora, 2000. godine čak $60 \%$ Britanaca putovalo je na odmor u inozemstvo u organizaciji turoperatora, a danas to još uvijek čini njih više od 50\% (ABTA 2018) i taj udio u posljednjih nekoliko godina ima uzlazni trend.

Zapadnoeuropske zemlje, u kojima je turoperatorsko poslovanje bilo najrazvijenije, povećale su udio svog emitivnog potencijala s $49 \%$ u 1966 . godini na 56\% u 1976. godini (EIU 1979: 34). U samo jednom desetljeću (1970. - 1980.) broj putnika u paket aranžmanima turoperatora baziranim na čarterskom zrakoplovnom prijevozu iz Europe u sredozemne destinacije porastao je s 5,4 milijuna na 12,8 milijuna (Pearce 1987: 291). Zapadnoeuropske zemlje, u kojima je turoperatorsko poslovanje bilo najrazvijenije, povećale su udio svog emitivnog potencijala s $49 \%$ u 1966. godini na 56\% u 1976. godini (EIU 1979: 34 ). S obzirom na to da se poslovanje obaju poslovnih subjekata temelji na principu ekonomije razmjera i ekonomije opsega, jer ovise o visokim stopama iskorištenja kapaciteta i širenju tržišta potražnje i ponude, međusobno umreženi postaju glavni generatori inozemnih turističkih putovanja i sinonim za masovni turizam.

Usporedimo li podatke vezane uz geografsku distribuciju međunarodnog turističkog prometa u svijetu prije nastanka turoperatora (1950.) s razdobljem kad turoperatori doživljavaju osobitu ekspanziju na europskom tržištu (1970. 2000.), moguće je zamijetiti bitne promjene (tablica 1). Međunarodna turistička kretanja proširila su se na veći broj zemalja, ali i unutar vodećih receptivnih zemalja znatno se promijenio njihov udio u ukupno ostvarenim međunarodnim turističkim dolascima (npr. Italija i Španjolska). U tom su se razdoblju turoperatori etablirali na tržištu kao iznimno poželjni poslovni partneri mnogih zemalja u razvoju jer im osiguravaju potrebnu masu klijenata i time ubrzan razvoj turizma $u$ kojem te zemlje vide potencijal za osiguranje nužnog deviznog priljeva kojim supstituiraju nedostatak ostvarenja izvoznih rezultata (Gilmor 1996). To se ne odnosi samo na zemlje u području Sredozemlja u koje su turoperatori najprije počeli usmjeravati turističku potražnju. Uvođenjem širokotrupnog aviona (Jumbo Jet) naglo je poraslo zanimanje za udaljene destinacije, pa je tako u razdoblju 1976. - 1986. samo s britanskog tržišta zabilježen rast paušalnih putovanja 
prema destinacijama udaljenim preko $3.500 \mathrm{~km}$ za 350\% (Euromonitor 1990: 48). Tako su nastale mnoge nove turističke destinacije na karipskom području te na području istočne Azije i Pacifika. Mnoge od tih destinacija početak turističkoga razvoja zahvaljuju upravo turoperatorima s njemačkog, britanskog i švicarskog tržišta. Oni su u te destinacije dovodili daleko više turista u paket-aranžmanima s europskog tržišta nego što je bio tržišni potencijal s njihova intraregionalnog područja (EIU 1994).

Prema podacima Njemačkog udruženja putničkih agencija i turoperatora (DRV 2000), udio organiziranih turističkih putovanja u odnosu na individualna turistička putovanja stalno raste. Tako je 1970. godine iznosio 17\% : 83\%, 1982. godine $26 \%: 74 \%$, a 2000 . godine porastao je na $44 \%$ : $56 \%$. Taj se omjer odnosi na ukupno realizirana turistička putovanja Nijemaca starijih od 14 godina i u trajanju dužem od pet dana, dakle na ona ostvarena u zemlji i u inozemstvu. Međutim, analizira li se organizacija putovanja samo na odmor $u$ inozemstvo, tada udio organiziranih putovanja na odmor u usporedbi s individualnim putovanjima raste na $58 \%$ : 42\% (RA 2004), a u slučaju putovanja na odmor u inozemstvo baziranih na čarterskom avioprijevozu udio u korist organiziranih putovanja doseže čak $80 \%$. Što su više turoperatori uključeni u organizaciju putovanja na odmor u inozemstvo, to je veći udio čarterskog zrakoplovnog prijevoza prema određenim destinacijama. To najbolje potvrđuju i sljedeći podaci: udio paušalnih putovanja u ukupno ostvarenim turističkim putovanjima na njemačkom tržištu iznosi 49\%. Međutim, analiziraju li se turistička putovanja u inozemstvo, uočljiv je dominantan trend putovanja u paket-aranžmanima. Turistički receptivne zemlje svijeta u koje se slijevaju organizirana putovanja iz Njemačke ostvarile su sljedeći udio u 2016. godini: Karibi 69\%, Portugal 63\%, Kanarski otoci $88 \%$, Mallorca 83\%, Španjolska ukupno 77\%, sjeverna Afrika 79\%, Grčka 77\%, Turska 66\% (RA 2017).

Slična situacija godinama vlada i na britanskom emitivnom turističkom tržištu. Tako je naprimjer udio paušalnih putovanja iz Velike Britanije u Grčku krajem 1990-ih godina dosegnuo 78,6\%, u Španjolsku 82\%, u Tursku 80,1\%, a u sjevernu Afriku 70,5\% (Cope 2000). U 2016. godini udio organiziranih putovanja na odmor $\mathrm{u}$ inozemstvo $\mathrm{u}$ odnosu na individualno organizirana putovanjima na tom tržištu iznosio je 51\% : 49\% u korist organiziranih putovanja (ABTA 2017). Međutim, ovdje treba istaknuti činjenicu da organizirana putovanja na britanskom tržištu doživljavaju renesansu. Prema tržišnim analizama (Mintel, kako je citirano u: Thomas Cook 2017), u razdoblju 2017. - 2021. godine potražnja za paušalnim putovanjima porast će $28,5 \%$, dok će istovremeno individualna turistička putovanja porasti za $17 \%$. 
Da paket-aranžmani ne nestaju s tržišta, potvrđuju i podaci u nastavku. Početkom devedesetih godina prošlog stoljeća europsko tržište organiziranih putovanja baziranih na čarterskom zrakoplovnom prijevozu dosegnulo je oko 40 milijuna putovanja (EIU 1992). Međutim, s obzirom na to da su iz te analize isključena paušalna putovanja bazirana na drugim oblicima prijevoza, jasno je da je veličina tržišta organiziranih putovanja bila jako podcijenjena (Čavlek 2006). Ekstrapolacijom raznih dostupnih podataka s vodećih turistički emitivnih i receptivnih tržišta Europe veličina europskog tržišta organiziranih putovanja na kraju 1990-ih procijenjena je na gotovo 70 milijuna putovanja (Čavlek 1998). Prema podacima Europskog udruženja turističkih agencija i turoperatora (ECTAA 2016), u Europi je 2015. godine prodano preko 180 milijuna paket-aranžmana.

Ovih tek nekoliko podataka upućuje na zaključak da su turoperatori u suradnji s čarterskim zrakoplovnim kompanijama revolucionirali međunarodna turistička putovanja jer su znatno utjecali na porast turističkih putovanja u inozemstvo. To se u konačnici bitno odrazilo i na geografsku redistribuciju međunarodnih turističkih tokova te na razvoj turizma $\mathrm{u}$ mnogim receptivnim zemljama $\mathrm{u}$ koje su navedeni subjekti usmjeravali turističku potražnju.

Omasovljenje međunarodnih turističkih putovanja u svijetu pod utjecajem turoperatora i čarterskih zrakoplovnih kompanija donio je tim gospodarskim subjektima status ,industrije“ jer su zapravo primjenom principa industrijske proizvodnje u području organizacije putovanja te vertikalnim i horizontalnim integracijama na emitivnom i receptivnom tržištu postali moćni i vrlo utjecajni dijelovi suvremenog sustava turizma (Čavlek 2013). Usporedbom postojećih podataka s glavnih emitivnih tržišta s podacima koji se odnose na različite receptivne zemlje u svijetu, može se utvrditi veza koja povezuje te opservacije u opću teoriju o visokoj korelaciji između turoperatora, čarterskog zrakoplovnog prijevoza i razvoja međunarodnog turizma.

Analiza navedenih podataka upućuje na zaključak da je spomenute poslovne subjekte opravdano smatrati poticateljima turističkog razvoja u mnogim zemljama širom svijeta. No u ocjeni važnosti turoperatora i čarterskih zrakoplovnih kompanija na razvoj turizma u određenim destinacijama nužno je uzeti u obzir još nekoliko važnih čimbenika. Nijedno odredište ne može postati turističkom destinacijom bez prometne infrastrukture i turističke infrastrukture, što znači da su za razvoj turizma potrebna znatna ulaganja. Pretvaranje određenog nepoznatog odredišta (u turističkom smislu) u turističku destinaciju iziskuje golema ulaganja. Stoga bi bilo nerealno očekivati da bi turoperatori i čarterske zrakoplovne kompanije mogle ući u takve financijske pothvate. Međutim, istraži li se organizacijska i vlasnička struktura tih poslovnih subjekata, slika njihove uloge na međunarodnom turističkom tržištu postaje puno jasnija. 
Svjetska turistička organizacija (UNWTO) i Svjetska trgovinska organizacija (WTO) tretiraju turističku aktivnost kao ekvivalent stvarnom izvozu robe za turistički receptivne zemlje (WTO 1998). Stoga pojedini autori smatraju da bi međunarodne turističke tokove trebalo objašnjavati tradicionalnom teorijom tokova trgovine (Zhang \& Jensen 2007), ali s tom razlikom što u slučaju trgovine uslugama u turizmu ljudi putuju u turističke destinacije jer se usluge u turizmu ne mogu konzumirali u domicilu. S druge strane, istraživanja na primjerima iz prakse poslovanja u turizmu upućuju na zaključak da se poslovni subjekti u turizmu ponašaju isto kao i subjekti u drugim industrijama jer su im za uspjeh na tržištu potrebni sofisticirani tehnološki inputi i odgovarajuće društveno planiranje (Zang \& Jansen 2007: 240). Isti autori, doduše, upozoravaju na činjenicu da je teoriju trgovine potrebno prilagoditi trgovini uslugama jer bolje razumijevanje trgovine uslugama daje odgovor na pitanje zašto neke zemlje ostvaruju bolje rezultate $\mathrm{u}$ turizmu od nekih drugih te koje su koristi zemalja u razvoju od liberalizacije njihove trgovine uslugama u turizmu i stalne tendencije povećanja broja inozemnih turista i inozemnih izravnih ulaganja (FDI) u turizam (Zang \& Jansen 2007).

Iako je trgovina relevantan pokretač industrijalizacije i omasovljenja turističkih putovanja, ipak teorija trgovine nije dovoljna za objašnjenje dinamike strukturnih promjena u ekonomiji (Memedovic \& Iapadre 2010). Stoga je važno istražiti načine na koje se ostvaruje kontrola nad određenim tržištem.

\section{Strukturne promjene na europskom turističkom tržištu}

Objedinjavanje proizvodnje i kapitala uobičajen je proces koncepcije razvoja poduzeća u svim zemljama tržišnoga gospodarstva, pa taj princip vrijedi i za organizatore putovanja. Povezivanje poslovnih subjekata radi smanjenja troškova poslovanja, jačanja konkurentske sposobnosti stvaranjem povoljnijih uvjeta na tržištu, ostvarivanja većeg udjela na tržištu i u konačnici ostvarivanja većeg profita glavni su razlozi koji su ih već u početnoj fazi razvoja poticali na okrupnjavanje (Čavlek 2000; Sinclair \& Stabler 2002).

Što se internacionalizacije poslovnih subjekata unutar turističkog sustava tiče, istraživanje je teško provoditi zbog nedostatka relevantnih informacija i podataka. Stoga se teorije multinacionalnih korporacija ne apliciraju na turizam (Buckley i Geyikdagi 1996). Uglavnom se većina istraživanja o utjecaju multinacionalnih ili transnacionalnih korporacija u području turizma odnosi na djelatnost ugostiteljstva, odnosno hotelijerstva, ali u usporedbi s objavljenim radovima o internacionalizaciji izvan sustava turizma, to je zanemarivo malo (Breda i Costa 2013). Nažalost, situacija u području turoperatorstva još je složenija, ali i lošija. Naime, transnacionalne ak- 
tivnosti turoperatora $\mathrm{u}$ turizmu ne odvijaju se njihovim vlastitim kapitalom (UN 2010) već kapitalom multinacionalnih korporacija u čijem su vlasništvu.

S obzirom na to da postoje znanstveni radovi koji ukazuju na opravdanost istraživanja strukturnih promjena na relativno maloj skupini djelatnosti koje su dio gospodarskog sustava (Silva i Teixeira 2008), strukturne promjene na europskom turističkom tržištu analizirat ćemo upravo $u$ domeni poslovnih subjekata orijentiranih na organizaciju međunarodnih turističkih putovanja vodećih turoperatora na europskom emitivnom tržištu.

Brojna istraživanja potvrdila su tezu da je stupanj internacionalizacije tercijarnog sektora do kraja 1980-ih bio relativno nizak (Breda i Costa 2013). No, ubrzani procesi globalizacije mijenjaju strukturu svjetskoga gospodarstva (Memedovic i Iapadre 2010), što se odražava i u promjeni relativne važnosti pojedinih gospodarskih sektora u svjetskoj ekonomiji, ali i u lokaciji pojedinih gospodarskih aktivnosti. Uslužni je sektor već krajem 1970-ih postao dominantan sektor u svjetskom gospodarstvu, a 2016. godine ostvario je udio od 65\% (World Bank 2017). Ubrzani rast međunarodnog turističkog prometa iznad stopa rasta svjetskoga gospodarstva utjecao je na porast trgovine uslugama, pa je doprinos turizma ukupnom svjetskom izvozu iz godine u godinu rastao te je u 2016. godini dosegnuo oko 30\% (WTTC 2017). To je rezultiralo i usmjeravanjem investicija u područje turizma, koji počinje privlačiti međunarodni kapital $\mathrm{u}$ one poslovne aktivnosti koje su dominantno orijentirane na međunarodno poslovanje, $u$ kojima se primjenjuju principi koji vrijede $u$ industrijskoj proizvodnji, a čiji su poslovni subjekti usmjereni na strategiju integracija s ciljem ostvarivanja rasta (Čavlek 2000; Hjalager 2007). Parafrazirajući Stiglitza (2002), promatrano s ekonomskog aspekta razvoja, turizam je i proces i posljedica ekonomske globalizacije. Song et al. (2017) ističu da je globalizacija izravna posljedica pojačane konkurencije na tržištu.

Do kasnih 1980-ih na europskom tržištu organiziranih putovanja dominirali su nacionalni i regionalni turoperatori, najčešće srednje veličine, a samo je nekolicina njih bila vertikalno integrirana s čarterskim zrakoplovnim kompanijama (Theuvsen 2003), i to na britanskom tržištu. Većina turoperatora ostvarivala je porast udjela i dominaciju na tržištu pretežno horizontalnim integracijama, odnosno spajanjima, pripajanjima ili kupovinom drugih turoperatora unutar domicilnog tržišta. Tako su se na vodećim emitivnim tržištima Europe, odnosno u industrijski razvijenim zemljama, stvarali sve veći i utjecajniji turoperatori koji dominiraju unutar pojedinih nacionalnih ekonomija u organizaciji turističkih putovanja za inozemstvo. No, mogućnost njihova neograničenog širenja na domaćem tržištu bila je limitirana zakonskim odredbama, kojima se sprečavalo stvaranje monopola. 
Međutim, stvaranjem jedinstvenog europskog tržišta 1993. godine te potpisivanjem Općeg sporazuma o trgovini uslugama (General Agreement on Trade in Services - GATS), koji je stupio na snagu 1995. godine i kojim je konačno regulirana materija prekograničnog kretanja usluga, omogućena je liberalizacija međunarodne razmjene usluga i stvoren je okvir za proširenje pružanja turističkih usluga, olakšani su kretanje ljudi vezanih uz spomenute usluge te ravnomjerniji turistički razvoj u svijetu (Vellas i Becherel 1995), a procesi integracija postaju vrlo dinamični jer su se otvorile nove mogućnosti za ulaganja i proširenje poslovanja europskih turoperatora na izvandomicilna tržišta. Zbog funkcionalne i prostorne fragmentacije globalnih lanaca vrijednosti, smanjila se ovisnost ekonomskih aktivnosti unutar nacionalnih granica (Memedovic i Iapadre 2010), što su turoperatorski koncerni počeli ubrzano koristiti ulaskom na tržišta izvan matične zemlje i širenjem svoga utjecaja na druga emitivna tržišta.

Internacionalizacija poslovanja, posredovanjem vertikalne integracije, omogućuje poslovnim subjektima uspostavljanje kontrole nad aktivnostima koje inače ne bi bile učinkovite $u$ tržišnim transakcijama (Weisfelder 2001). Razlozi primjene strategija vertikalnih integracija u turoperatorskom poslovanju ne mogu se objasniti „resursnom osnovom“ (Theuvsen 2004), odnosno osiguravanjem resursa za "proizvodnju“ paket-aranžmana jer njihov uspjeh na tržištu prije svega ovisi o kreiranoj marki proizvoda, pristupu tržištu ponude usluga i kanalima distribucije te dobrom poznavanju relevantnih tržišta. S obzirom na to da turoperatori u svoj proizvod kombiniraju niz različitih usluga koje pružaju i kontroliraju različiti pružatelji usluga na različitim tržištima (prijevoz, smještaj, transfer, rent-a-car, osiguranje, zabava, izleti itd.), za turoperatore je od presudne važnosti uspostaviti vlastitu nadležnost i kontrolu unutar tog lanca vrijednosti. Naime, prema Smjernici Europske unije o putovanju u paket-aranžmanu, turoperatori su prema potrošačima jedini odgovorni za neizvršenje ili manjkavo izvršenje bilo koje usluge iz cjelokupnoga lanca vrijednosti. Stoga, za bolje razumijevanje razloga za primjenu strategije vertikalnih integracija u domeni organiziranih putovanja potrebno je imati na umu činjenicu da je turoperatorstvo iznimno „koordinacijski intenzivna“ djelatnost kod koje financijski uspjeh uvelike ovisi o organizacijskim sposobnostima, odnosno „superiornoj koordinaciji unutar različitih faza turističkog lanca vrijednosti“ (Theuvsen 2004: 477). Vertikalne integracije omogućavaju podizanje organizacijskih sposobnosti time što turoperatori postaju glavni koordinatori između različitih poslovnih subjekata i njihovih poslovnih procesa te na taj način stvaraju nužnu osnovu za postizanje i održavanje konkurentske prednosti na tržištu. Integrirani model poslovanja omogućuje postizanje nadmoći u distribuciji na emitivnim tržištima i optimi- 
zaciju volumena turističke potražnje koju onda usmjeravaju prema vlastitim kapacitetima i na taj način maksimaliziraju prihode te istovremeno smanjuju rizike od nedovoljne iskorištenosti kapaciteta. Uz to, kreiranjem diferenciranog proizvoda koji kontroliraju u svim fazama izvedbe, ciljano usmjeravaju potražnju prema destinacijama u kojima najbolje ostvaruju svoje poslovne interese, ali stvaraju i prepreke ulasku konkurencije na ta tržišta. No, za uspostavljanje takve organizacijske strukture nužna su velika ulaganja pa se, s obzirom na njihove niske profitne stope, postavlja pitanje tko može financirati sve te kupovine i spajanja kojima će se postići nužna kontrola unutar čitavog lanca vrijednosti.

$\mathrm{S}$ obzirom na to da su globalizacijski procesi postali glavni megatrend $\mathrm{u}$ razvoju svjetskog gospodarstva, turizam je prepoznat kao glavna snaga $u$ tom procesu (Cohen 2013: 104). Potencijale rasta i razvoja međunarodnog turizma ubrzo prepoznaje i međunarodno tržište kapitala, koje pronalazi nove prilike za bržu oplodnju kapitala. Upravo je financijski kapital multinacionalnih korporacija unio stratešku snagu turoperatorskim koncernima, na što će analiza u nastavku i ukazati.

Kontrolu nad razvojem ostvaruje onaj tko kontrolira kretanje kapitala. Kao što je to slučaj i s drugim gospodarskim aktivnostima, multinacionalne korporacije glavni su kontrolori razvoja i u domeni organiziranih putovanja. Širenje interesa multinacionalnih korporacija $u$ područje turizma kontinuirani je trend (UNWTO 2011) i on je bitno utjecao na promjenu postojeće vlasničke strukture turoperatorskih koncerna koji u tom procesu postaju privlačni vrlo širokom spektru ulagača (od banaka, osiguravajućih društava, mirovinskih fondova i industrijskog kapitala do izdavačkih i medijskih konglomerata, kao i mnogih drugih).

Dugogodišnjim praćenjem konsolidacijskih procesa upravo u domeni turoperatorskog poslovanja i analizom njihovih relevantnih pokazatelja iz godišnjih izvještaja u razdoblju 1995. - 2017. godine moguće je doći do zaključka da su turoperatori do danas prošli pet konsolidacijskih faza kojima se postupno mijenjala ne samo njihova organizacijska i vlasnička struktura već i struktura kako turistički emitivnog tako i receptivnog tržišta u Europi.

Kako su se na europskom tržištu paralelno razvijala dva različita koncepta integracijskih procesa unutar turoperatorskog poslovanja: britanski, po kojem su se turoperatori vertikalno povezivali s čarterskim zrakoplovnim kompanijama, i njemački, koji je dominantno slijedio princip horizontalnih integracija te čvrstih ugovornih odnosa s hotelskim poduzećima u turističkim destinacijama (Čavlek 2000), u tim je integracijskim procesima došlo do polarizacije interesnih sfera. Vodeći britanski turoperatori svoju su ekspanziju na izvandomicilna tržišta usmjerili na slično strukturirano irsko i skandinavsko tržište, a vodeći 
njemački turoperatori okrenuli su se tržištima u kontinentalnom dijelu Europe te su kupovinama vodećih turoperatora na holandskom, belgijskom, austrijskom i francuskom tržištu preuzeli kontrolu organizacije putovanja u inozemstvo s tih tržišta. Tako su i jedni i drugi do 1997. godine ovladali svaki svojim dijelom europskog tržišta organiziranih putovanja i time je okončana prva faza „europeizacije“ njihova poslovanja (Čavlek 2000), koja je rezultirala stvaranjem jakih oligopola (Bastakis et al. 2004).

Drugu fazu konsolidacije, koja počinje u drugoj polovici 1998. godine, obilježili su najintenzivniji integracijski i konsolidacijski procesi u dotadašnjoj povijesti razvoja turizma u kojoj se za prevlast nad cjelokupnim europskim tržištem organiziranih putovanja izravno bore dva njemačka turoperatorska koncerna - TUI i NUR. No, glavnu stratešku prevagu u toj konkurentskoj borbi unosi ulazak industrijskog kapitala u turoperatorsko poslovanje. Naime, Preussag, njemački industrijski konglomerat, u čijem je vlasništvu i holding Hapag Lloyd (s brodskom i čarterskom zrakoplovnom kompanijom), postaje većinski vlasnik tada već najvećeg europskog turoperatora TUI-ja sa sjedištem u Njemačkoj. Zahvaljujući Preussagovu kapitalu, dolazi do vertikalne integracije TUI-ja i čarterske zrakoplovne kompanije u sastavu holdinga Happag Lloyda. Njihovim spajanjem stvoren je novi holding pod nazivom HTU (Hapag Touristik Union), koji kasnije mijenja ime u TUI Group. Bio je to odgovor na okrupnjavanje drugog po veličini turoperatora na njemačkom tržištu, NUR-a (u vlasništvu lanaca robnih kuća i kataloške prodaje u Njemačkoj - koncerna Karstadt/Quelle), koji je vertikalnom integracijom s čarterskom zrakoplovnom kompanijom Condor (u vlasništvu Lufthanse) stvorio novi holding pod nazivom CEN Touristik (Condor \& Neckermann).

$\mathrm{S}$ obzirom na to da su $\mathrm{u}$ toj fazi konsolidacije vodeći njemački turoperatori svoju organizacijsku strukturu prilagodili poslovanju na tržištu organiziranih putovanja baziranih na čarterskom avionskom prijevozu, stvorili su uvjete za ulazak na drugo po veličini tržište organiziranih putovanja u svijetu - tržište Velike Britanije.

Uslijedila je treća faza konsolidacije i borba za prevlast na britanskom tržištu. Majka kompanija TUI-ja 2000. godine kupuje Thomson Travel, najveći britanski turoperatorski koncern vertikalno povezan s najvećom čarterskom zrakoplovnom kompanijom na svijetu - Britanniom Airways - te se time čvrsto pozicionira kao vodeći turoperatorski koncern u Europi. Istovremeno, majka kompanija koncerna $C \mathcal{E N}$ kupuje trećeg po veličini organizatora putovanja na tom tržištu - Thomasa Cooka - te preuzima i njegovo ime, koje je najprepoznatljivija marka organizatora putovanja u svijetu. Tako nastaje drugi po veličini turoperatorski koncern u Europi - Thomas Cook PLC. Na taj način britanski turoperatorski kon- 
cern My Travel Group potisnut je na treće mjesto u Europi. U međuvremenu na njemačkom turističkom tržištu ulaganjem kapitala Rewe grupacije, jednog od najvećih trgovačkih lanaca robe široke potrošnje, stvara se četvrti turistički megakoncern spajanjem sedam njemačkih turoperatora srednje veličine s još nekoliko poslovnih jedinica u inozemstvu.

U četvrtoj fazi konsolidacije na europskom tržištu organiziranih putovanja, koja završava 2007. godine, TUI-jev koncern spaja se s četvrtim po veličini britanskim turoperatorskim koncernom First Choice, u kojem majka kompanija TUI-ja ima 51\% vlasništva dionica, a First Choice 49\% dionica. Gotovo istovremeno Karstad/Quelle AG spaja svoj koncern Thomas Cook s britanskim My Travelom te nastaje Thomas Cook PLC, u kojem 52\% vlasništva ima Karstadt/Quelle, a 48\% vlasništva dioničari koncerna My Travel. Oba turoperatorska koncerna počinju kotirati na Londonskoj burzi (TUI 2017; Thomas Cook 2017). Britansko je tržište tako postalo najkoncentriranije tržište organiziranih putovanja u svijetu na kojem TUI Group i Thomas Cook Group kontroliraju 3/4 svih paušalnih putovanja u inozemstvo s tog tržišta (TUI 2017).

Globalizacija napreduje u razmjerima i opsegu, ali njezini dosezi nisu ravnomjerno raspoređeni unutar određenih gospodarskih aktivnosti i poduzeća, a ni unutar nacionalnih ekonomija, pa onda ni unutar regija (Hjalager 2007). Teoriji u turizmu kao da izmiču iz područja znanstvenog interesa detaljni uvidi u promjenu strukture lanca vrijednosti kojim multinacionalne korporacije realociraju kapital i uspostavljaju kontrolu nad tokovima turističke potražnje i razvoja turizma u turistički receptivnim zemljama u kojima međunarodni kapital pronalazi svoj interes. Postoje brojni primjeri u svijetu koji mogu potvrditi Theunsovu tvrdnju (2008.) da se moć države smanjuje s povećavanjem moći globalnog kapitala.

$S$ obzirom na to da su turoperatori dominantno orijentirani na organizaciju putovanja u inozemne destinacije, jasno je da im je liberalizacija i globalizacija svjetskog tržišta otvorila mogućnost stjecanja vlasništva ili suvlasništva nad poslovnim subjektima u turističkim destinacijama gdje se pružaju usluge klijentima koje oni dovode na ta tržišta. Tako su se uz horizontalne i vertikalne integracije na turistički emitivnim tržištima gotovo simultano odvijale i vertikalne integracije na turistički receptivnim tržištima, pa se portfelj multinacionalnih korporacija proširio na cjelokupni lanac vrijednosti u domeni organiziranih putovanja, od hotela i receptivnih turističkih agencija do flote brodova za krstarenja. Tako se tržišna utakmica s emitivnih turističkih tržišta nastavila i na receptivnim tržištima. U tom je procesu turoperatorski koncern TUI posao „najvećim hotelijerom“ Njemačke koji u turistički receptivnim zemljama u svom vlasništvu/suvlasništvu ili pod ugovorom o upravljanju ima 380 hotela i 238.775 
hotelskih kreveta raspoređenih od Španjolske, Grčke, Egipta, Tunisa, Maroka, Turske, Austrije i Meksika do brojnih karipskih destinacija, a njegove su najpoznatije marke hotelskih lanaca RIU, Robinson, Blue Diamond, TUI Magic Life, Grupotel i Iberostar (TUI 2017). Najpoznatije su marke hotelskih lanaca u vlasništvu Thomasa Cooka - Iberostar, Sunwing i Aqua Sol (Thomas Cook 2017).

Spomenuti integracijski i konsolidacijski procesi doveli su do bitne promjene same strukture europskog turističkog tržišta (Dwyer 2015; Smeral 1998). Stvorena je takozvana „dualna struktura turizma“: prva, koju Keller (2001.) naziva „industrijom putovanja“, a koju čine zrakoplovne kompanije i turoperatori kao najvažniji predstavnici multinacionalnih korporacija lociranih na turistički emitivnim tržištima, te druga, koja je stacionirana u turistički receptivnim zemljama i kojom dominiraju mala i srednja poduzeća (SME).

Europski turoperatorski koncerni, kao dijelovi velikih multinacionalnih korporacija, kontroliraju „proizvodnju“, distribuciju i konzumaciju usluga organiziranih putovanja. Time stječu sve veću kontrolu poslovanja u mnogim turističkim destinacijama jer, kao što je navedeno u godišnjem izvještaju, TUI je „istovremeno onaj koji razvija proizvod, investira i upravlja“ (TUI 2017) razvojnim procesima u turizmu te postavlja nove standarde poslovanja na međunarodnom turističkom tržištu.

Istraživanja odnosa između hotelskih poduzeća i turoperatora u sredozemnim destinacijama (Bastakis et al. 2004; Buhalis 2000; 2002; Dwyer 2015; Karamustafa 2000; Koutoulas 2006; Medina-Muñoz et al. 2003;) jasno ukazuju na snagu kontrole koju europski turoperatorski koncerni imaju na mnogim turistički receptivnim tržištima.

Poslovnu logiku, odnosno logiku ulaganja kapitala u tom procesu lako je prepoznati. Kapital jednostavno slijedi turističke potrošače i ostvaruje svoj glavni cilj: participiranje u ostvarenom profitu i u onom dijelu lanca vrijednosti koji se nalazi u turističkim destinacijama. Turoperatori, kao dijelovi velikih multinacionalnih korporacija u turizmu, uspjeli su objediniti sve dijelove lanca vrijednosti te usmjeravaju turističku potražnju prema onim tržištima za koja su zainteresirane multinacionalne korporacije u čijem su oni vlasništvu. Podaci u tablici 4 barem djelomično ilustriraju koncentraciju moći u rukama dvaju najvećih koncerna u domeni organizacije turističkih putovanja u svijetu. 
Tablica 4. Usporedba osnovnih podataka o vodećim koncernima u domeni organizacije turističkih putovanja: TUI grupacija i Thomas Cook grupacija

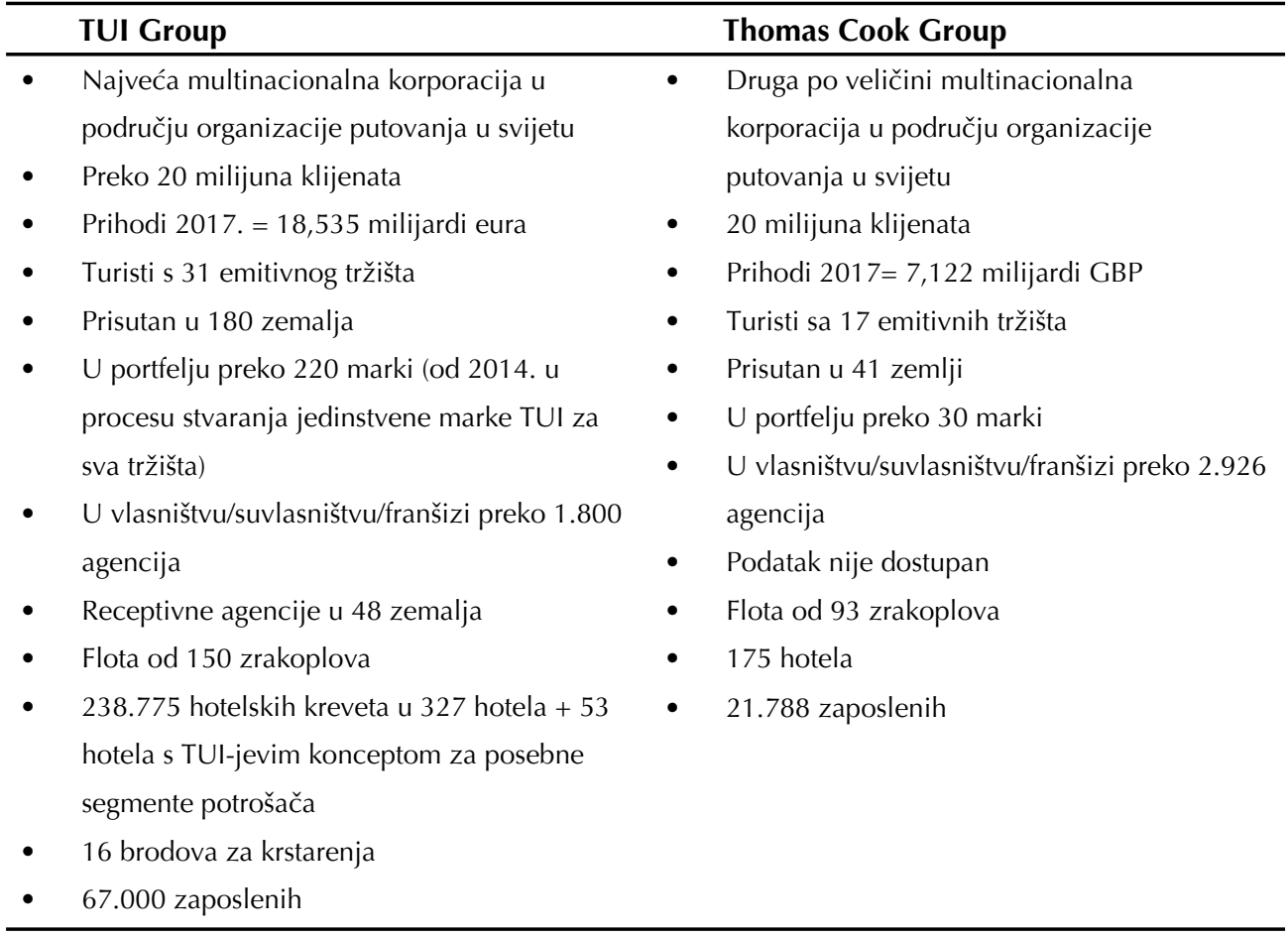

Izvor: sastavljeno prema podacima iz TUI Group Annual Report (2017.). https://www.tuigroup.com/en-en/investors/special-annual-report-17 i Thomas Cook Annual Report and Accounts (2017.) http://www.annualreports.com/HostedData/AnnualReports/PDF/LSE_TCG_2017.pdf

U petoj fazi konsolidacije karakter turističke ponude i potražnje počinje se naglo mijenjati pod utjecajem nove informacijsko-komunikacijske tehnologije, porasta utjecaja niskobudžetnih zrakoplovnih kompanija i brojnih inovacija te se cijeli turistički sustav transformira (Buhalis 2003; Buhalis \& O'Connor 2005). Turistički potrošači počinju se naglo okretati mrežnim (on-line) kanalima distribucije i u tom procesu mnogi počinju prognozirati kraj turoperatorskog poslovanja. Novi odnosi na turističkom tržištu doista su utjecali na pad zanimanja za organizirana putovanja. No, ne zadugo. Turoperatorski koncerni brzo uspostavljaju ravnotežu u novonastaloj situaciji „asimetrije moći“ na tržištu (Ford et al. 2012). 
Kao što je dosadašnja analiza konsolidacijskih procesa pokazala, europsko tržište organiziranih putovanja nema više prostora za značajniji rast, pa se vodeći turoperatorski koncerni, odnosno multinacionalne korporacije u čijem su oni vlasništvu, počinju okretati prema tržištima koja pokazuju vrlo dobre potencijale za daljnji rast, a to su prije svega tzv. tržišta BRIC zemalja (Brazil, Ruska Federacija, Indija i Kina). Te zemlje postaju okosnica njihova daljnjeg strateškog razvoja i glavni pokretač njihova dugoročnoga rasta (Čavlek 2018). TUI i Thomas Cook već su 2011. godine osigurali dozvolu poslovanja na kineskom tržištu. S druge strane, vodeći turoperatorski koncerni ulažu milijune eura u najsuvremeniju informacijsko-komunikacijsku tehnologiju i mrežne kanale distribucije, a ne ispuštaju iz kontrole ni klijente niskobudžetnih avioprijevoznika (LCC) te u svome sastavu već imaju i njih. U strateškom planu razvoja TUI navodi da će do 2022. godine s tržišta Brazila i Kine prihodovati dodatnu milijardu eura (TUI 2017). S druge strane, Thomas Cook sklapa strateška partnerstva s Expediom, jednom od najvećih mrežnih turističkih agencija u svijetu, i unapređuje svoja mrežna tehnološka rješenja za izravnu distribuciju usluga klijentima.

No, valja nakraju upozoriti na još jednu važnu činjenicu. Na tržištu organiziranih turističkih putovanja u Europi donedavno gotovo da nisu ni postojala ulaganja izvaneuropskoga kapitala u europske turoperatore (s izuzetkom kanadskog i američkog kapitala u neke od britanskih turoperatora i japanskog kapitala u Club Med). Međutim, ta se situacija iz temelja mijenja jer su i kineski investitori dobili dozvolu ulaganja kapitala na inozemna tržišta. Oni pokazuju vrlo velik interes za ulaganja u poslovne subjekte u turizmu. Tako je francuski organizator putovanja Club Med već $100 \%$ u rukama kineskoga kapitala, dio vlasništva dionica Thomasa Cooka također, a tržišni analitičari ističu da za gotovo svako preuzimanje nekog turističkog poslovnog subjekta sa Zapada postoji barem jedan kineski ulagač koji se natječe za tu kupovinu (Čavlek 2018). To će svakako imati znatne posljedice na nove konsolidacijske procese, ali ovaj put izvan europskog turističkog tržišta. Kineski kapital sigurno će unijeti promjene u strukturu turističkog tržišta kakvu danas poznajemo. Strukturne promjene svjetske ekonomije rezultat su, između ostalog, i ubrzanih tehnoloških promjena, a one će imati sve veći utjecaj i na poslovne subjekte u turizmu, ali i na turiste. 


\section{ZAKLJUČAK}

Iako je iznimno teško analizirati razvoj međunarodnog turizma u svijetu vezujući ga uz nastanak i razvoj turoperatora i čarterskih zrakoplovnih kompanija, prezentirana analiza ipak upućuje na zaključak da se radi o velikom međusobnom utjecaju. Prije svega ti su poslovni subjekti zaslužni za pokretanje turističke potražnje niže i srednje platne moći; utjecali su na povećanje udjela inozemnih turističkih putovanja; pridonijeli su ravnomjernijoj geografskoj distribuciji turističkih tokova u svijetu; utjecali su na promjenu strukture turističkog tržišta kojom su osigurali diktiranje uvjeta poslovanja ne samo na emitivnim već i na receptivnim tržištima.

Koji god oblik organizirana putovanja u budućnosti poprimala, organizatori putovanja svoje će mjesto na tržištu osiguravati prvenstveno individualizacijom, personalizacijom usluge i brigom za sigurnost potrošača. Nema sumnje u to da će se konkurencija na turističkom tržištu svakodnevno zaoštravati, da će se postojeći model „proizvodnje“ i distribucije usluga u turizmu uvelike mijenjati zbog mogućnosti korištenja sve sofisticiranijih tehnoloških rješenja, ali i mogućnosti korištenja umjetne inteligencije. Postojeći klasični model poslovanja turoperatora pod sve je većim pritiskom. Međutim, valja upozoriti na činjenicu da su turoperatorski koncerni naviknuti na poslovanje u različitim kriznim situacijama, da su se do sada uspješno prilagođavali promjenama i novim trendovima na tržištu, stoga je teško zamisliti da će multinacionalne korporacije u domeni organiziranih putovanja dozvoliti ispuštanje multimilijardi eura vrijedan posao iz svojih ruku.

Conditio sine qua non njihova opstanka na tržištu ostat će i dalje međusobno povezivanje i umrežavanje različitih poslovnih subjekata s ciljem kreiranja dodane vrijednosti za turističke potrošače. Stoga će pritisak na inovacije proizvoda biti sve izraženiji. Za razvoj i inovacije potrebna su pak značajna financijska sredstva. Tko ne bude mogao osiguravati potrebne izvore financiranja, neće biti u mogućnosti kreirati proizvod kojim će konkurenciju raznih mrežnih platformi moći držati postrani. Može se očekivati da će umjetna inteligencija postati jedan od glavnih pokretača promjena. No, ona može pružiti i velike šanse postojećim organizatorima putovanja. Korištenjem umjetne inteligencije mogli bi svoju konkurentsku sposobnost dignuti na još višu razinu i spriječiti da im mjesto na tržištu preuzmu čisti digitalni giganti. Turizam se itekako koristi novom tehnologijom, ali suština turističkih putovanja nije $u$ tehnologiji.

Za turistički receptivne zemlje najvažnije je prepoznati međunarodno konkurentsko okruženje u kojem se nalaze. Presudno će biti osiguravanje fi- 
nancijskog i ljudskog kapitala, a oni su pak ograničeni. Zasigurno neće biti dovoljno imati samo dobar proizvod nego će biti nužna umreženost s relevantnim investitorima.

O tome tko će opstati, tko će rasti i razvijati se te tko će koga istisnuti s tržišta - odlučivat će snaga kapitala. Parafrazirajući onu poznatu izreku o pogledu optimista i pesimista, može se zaključiti da neće biti toliko važno raspravljati o tome je li čaša polupuna ili poluprazna već će od presudne važnosti biti tko je vlasnik te čaše. 


\section{LITERATURA}

ABTA (2018). Travel Trends Report 2018. https://www.abta.com/sites/default/files/ media/document/uploads/ABTA_Travel_Trends_Report_2018_0.pdf

Aramberri, J. (2009). The future of tourism and globalisation: Some critical remarks, Futures, Volume 41, str. 367-376.

Breda, Z. \& Costa, C. (2013). The Internationalisation Process of Tourism Firms: The Case of the Hotel Sector, u Handbook of Tourism Economics: Analysis, New Applications and Case Studies, C. Tisdell (ed.), World Scientific Publishing: Singapore, pp. 137-170. ISBN: 978-9814327077.

Buckley, P.J. \& Geyikdagi (1996). A theoretical explanation of international tourism investments. Annals of Tourism Research, 23(4), 941-943.

Buhalis, D. (2003) eTourism - Information Technology for Strategic Tourism Management. Harlow: FT Prentice Hall.

Buhalis, D. and O'Connor, P. (2005) 'Information communication technology revolutionizing tourism', Tourism Recreation Research, 30(3): 7-16.

Burkart, A. J., \& Medlik, S. (1974). Tourism - Present, Past, and Future. London: Heineman.

Cope, R. (2000). UK Outbound. Travel E Tourism Analyst, 1:19-39.

Cooper, C., Fletcher, J., Fyall, A., Gilbert, D. \& Wanhill, S. (2008). Tourism: Principles and Practice, Harlow: Pearson Education, ISSN: 978-0-273-71126-1.

Čavlek, N. (2018). Tourism Distribution and Intermediaries, u The SAGE Handbook of Tourism Management, C. Cooper, S. Volo, W.C. Gartner \& N. Scott (eds.), SAGE Publications Ltd: London, pp. 269-285. ISBN: 9781526461131. DOI: http://dx.doi. org/10.4135/9781526461490.n19

Čavlek, N. (2013). Travel and Tourism Intermediaries: Their Changing Role, u Handbook of Tourism Economics: Analysis, New Applications and Case Studies, C. Tisdell (ed.), World Scientific Publishing: Singapore, pp. 191-206. ISBN: 978-9814327077.

Čavlek, N. (2006). Travel and tourism intermediaries, u International Handbook on the Economics of Tourism, L. Dwyer \& P. Forsyth (eds.), Edward Elgar: Northampton, pp. 155-172. ISBN-13:978 1843761044.

Čavlek, N. (2000). The Role of Tour Operators in the Travel Distribution System. u Trends in Outdoor Recreation, Leisure and Tourism, W.C. Gartner \& D.W. Lime (eds.), CABI Publishing: Oxton, New York, pp. 325-334. ISBN 0851994032.

Čavlek, N., (1998). Turoperatori i svjetski turizam, Zagreb, Golden marketing, ISBN: 953-6168-73-1. DRV (2000). Zahlen und Fakten zum deutschen Reisemarkt.

Dwyer, L. (2015). Globalisation of tourism: Drivers and outcomes. Tourism Recreation Review, 40(3), 326-339.

ECTAA (2016). Table of Statistics -European Travel Agents and Tour Operators Statistics -European Travel Agents and Tour Operators http:/www.ectaa.org/ files/cms/ad17-085-448.pdf 
EIU (1979). International Tourism Development Forecasts to 1990. Special Report, No. 62, London.

Euromonitor (1990). The UK Travel and Tourism Report 1990. London: Euromonitor

Ford, R.C., Wang, Y. and Vestal, A. (2012) 'Power asymmetries in tourism distribution networks', Annals of Tourism Research, 39(2): 755-79

Gillmor, D. (1996) 'Evolving air-charter tourism patterns: change in outbound traffic from the Republic of Ireland', Tourism Management, 17(1): 9-16.

Hjalager, A-M. (2007). Stages in the economic globalisation of tourism, Annals of Tourism Research, 34(2):437-457.

Hollway, J. C. (1998). The Business of Tourism. Harlow: Longman. ISBN 0-582-32-881-0.

Memedović, O. \& Iapadre, L. (2010). Structural Change in the World Economy: Main Features and Trends. Vienna: United Nations Industrial Development Organization.

Goeldner, C. \& Ritchie, J.R.B. (2009). Tourism-Principles, Practices, Philosophies. New York: John Wiley \& Sons. ISBN 978-0-470-08459-5.

Mill, R.C. \& Morrison, A.M. (1985). The Tourism System - An Introductory Text. London: Prentice-Hall. ISBN: 978-0139231452

Mundt, J.W. (2011). Reiseveranstaltung. Munich: De Gruyter Oldenbourg. ISBN: 9783486704501.

Pearce, D. (1987). Mediterranean Charters - A Comparative Geographic Perspective. Tourism Management, December, 291-305.

Poon, A. (2000). Germany Outbound. Travel and Tourism Analyst, 4, 17-36.

RA (2017). ReiseAnalyse - Erste ausgewählte Ergebnisse der 47. Reiseanalyse zur ITB 2017. Prezentacija na ITB-u.Hamburg: F.U.R.

RA (2004). Reiseanalyse Aktuell, Hamburg: F.U.R.

Silva, E. G. \& Teixeira, A.C. (2008). Surveying structural change: Seinal contributions and a bibliometric account, Structural Change and Economic Dynamics 19.

Sinclair, M. T. \& Stabler, M. (2002). The economics of Tourism, London: Routledge. ISBN: 020330795X 9780203307953.

Song, H., Li, G. and Cao, Z. (2017). Tourism and Economic Globalization: An Emerging Research Agenda, Journal of Travel Research, pp. 1-13.DOI: $10.1177 / 0047287517734943$

Statistica (2018). https://www.statista.com/outlook/266/100/package-holiday/worldwide

Stiglitz, J. (2002). Globalisation and its Discontents. London: Penguin Group.

Theuvsen, L. (2004). Vertical Integration int he European Package Tour Business. Annals of Tourism Research, 31(2), pp. 475-478.

UN (2010). Promoting Foreign Investment in Tourism, United Nations Conference on Trade and Development. Investment Advisory Series, Series A, No. 5. New York: Unated Nations. 
UNWTO (2018). Tourism Highlights, 2018 Edition.

UNWTO (2018). Tourism Highlights, 2017 Edition.

UNWTO (2017). Tourism Highlights, 2016 Edition.

UNWTO (2008) Tourism Market Trends, 2007 Edition - World Overview.

Vellas, F. \& Becherel, L. (1995). International Tourism. London: MacMillan. ISBN: 978333615232.

Youell, R. (1994). Leisure and Tourism. London: Pitman Publishing. ISBN: 0582278422.

Weisfelder, C.J. (2001). Internationalization and the multinational enterprise: Development of a research tradition. In Reeassessing Internationalization of the Firm, CN Axinn \& P. Matthyssens (eds.), Vol. 11, str. 13-46. Amsterdam: JAI Press.

World Bank (2017). World development indicators: Structure of output. http://wdi. worldbank.org/table/4.2

WTO (1998). Tourism Service: Background Note by Secretariat. World Trade Organisation, Council for Trade in Services (23 September).

WTTC (2018). Travel \& Tourism Economic Impact 2018 World. World Travel and Tourism Council. https://www.wttc.org/-/media/files/reports/economic-impact-research/regions-2018/world2018.pdf

Zang, J. \& Jensen, C. (2007). Comparative Advantage - Explaining Tourism Flows. Annals of Tourism Research 34(1), pp. 223-243. 


\section{Summary}

\section{Who is Steering the World's Tourist Trends}

Although it is exceptionally difficult to analyse the development of international tourism in the world by tying it to the emergence and development of tour operators and charter airline companies, this analysis supports the conclusion that they impact each other significantly. Above all, these business entities are credited for driving middle and low yield tourist demand; for increasing the share of international tourism; for contributing to a more balanced geographical distribution of tourism flows in the world; and for leveraging the changes in the tourism market structure that secured them the position to dictate the conditions for operating in both out-bound and inbound markets.

Regardless of the format that organized tourism takes in the future, tour organizers will ensure their market position primarily by individualization, by personalized services and by their concern for the consumer's safety. Undoubtedly, the competition in the tourism market will escalate on a daily basis and the existing model of 'production' and distribution of tourism services will change profoundly due to a facilitated use of ever more sophisticated technological solutions, including artificial intelligence. The current model of tour operators' business operation is under growing pressure. Nevertheless, it should be noted that tour operators are accustomed to operating in different crisis situations, that up to present day they have successfully adapted to the changes and new trends in the market. Therefore, it is difficult to conceive that MNCs will let the multi-billion euro business in the domain of organised tourism slip between their fingers.

Mutual ties and networking of different business entities to create value added for the tourism consumers will remain the conditio sine qua non of their survival in the market. Therefore, the pressure for innovative products will become more and more prominent. Nevertheless, development and innovation require significant financial resources, and those who fail to secure the necessary funding will not be able to create new products to keep the competition of various on-line platforms aside. Artificial intelligence is expected to become the key driver of change, but it can also offer great opportunities for the existing tourism and travel organizers. By using artificial intelligence, they could raise their competitive advantage to an even higher level and prevent having their market share taken over by pure digital giants. Tourism uses new technologies indeed, but the gist of tourism travel does not rest in technology.

For tourism inbound countries it is most important to recognise their international competitive environment. Ensuring financial and human capital will be crucial, although they are quite limited. Having a good product alone will be insufficient most certainly, but strong networks with the relevant investors will be indispensable.

Who will survive, who will grow and develop, who will push whom out of the market - all these issues will be decided by the power of capital. Paraphrasing the well-known dictum about the optimists' and the pessimist's perspectives, a conclusion may be drawn: the question whether the glass is half-full or half-empty will not be as significant as the question who owns the glass. 